\title{
アルコール処理酵母による「生臭み」 低減ワインの開発
}

募魚や魚の干物と清酒は相性が良いのに, ワインとは相性が悪く, 非常に生臭く感じる。これはワインに 含まれる 2 価の鉄イオンが触媒になって魚介類に含まれる過酸化脂質が分解され, カルボニル化合物が生 じることが原因である。では，ワインの鉄含量を低くするにはどうすればよいのか？ 筆者らは, シュール リーのワインでは鉄含量が低いことにヒントを得て, アルコール処理をした酵母を添加することでワインの 鉄含量を低下する技術を開発した。その詳細を解説していただいた。

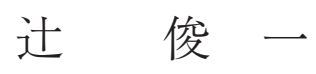

\section{はじめに}

お酒を飲む時にどんな料理を一緒に食べるかによっ て, 食事全体の評価が変わることは多くの方が経験し ていることではないだろうか。一般的には，「赤身の 肉には赤ワイン, 白身の肉や魚には白ワイン」が合う というワインと料理を選ぶ上での基本的な考え方があ る。しかしながら，この考え方に沿って，食事に合う ワインを選んでも，全てが思い通りに行く訳ではない。 例えば，日本で食されている一般的な魚介料理と特定 のワインの組み合わせは，しばしば合わないと言われ ている。では, どのような点で合わないのか。日本に 限らず, 赤ワインと魚介料理の組合せは衝突すると言 われることがある。その理由は, 赤ワインに含まれる タンニンによって, 金属味や金属臭, 魚臭さ, 苦味な どが生じてしまうからだと言われている ${ }^{1,2)}$ 。しかし ながら，ほとんどタンニンの含まれていない白ワイン でも魚介類と合わないことが言われており ${ }^{3)}$, 経験的 な法則が絶対ではないことも少しずつ分かってきた。

そんな中，田村らはワインと魚介類を食べ合わせた時 に, ワイン中に含まれる数 $\mathrm{mg} / \mathrm{L} の 2$ 価鉄イオンが 魚介類に含まれる脂質の酸化を促進することで,「生 臭み」を発生させることを明らかにした ${ }^{4,5)}$ 。つまり， 鉄イオンの少ないワインを開発できれば, 魚介料理を
台無しにしない, 良いワインと魚介料理の組合せが成 立できる。魚介料理の多い日本において, ワインと魚 介料理が「合わないもの」と誤解されないためにも, 鉄を低減したワインを開発し, 日本の食卓でワインを より多くの方に楽しんでもらうことを目的として研究 を行ったので, その結果について報告したい ${ }^{6.7)}$ 。

\section{1. 背 景}

まずは, ワインと日本の魚介料理が合わない,つま り本稿で扱う「生臭み」について詳細を述べておきた い。ワインと魚介料理を口の中で合わせてはじめて感 じる不快な生臭みを研究対象とし, 魚介類そのものが もっているにおいは取り扱わない。では, 実際にどの ような魚介料理が「生臭み」を発生させやすいのか。 田村や藤田らの研究により,「生臭み」の発生には, 魚介に含まれる過酸化脂質が深く関わっていることが 示唆されておりり ${ }^{3.5)}$, さらに口の中で発生する「生臭 み」を抑えるには, オリーブオイルなどの油を添加す ることが有効だということも報告されている ${ }^{8)}$ 。日本 では，脂肪分の多い魚介類（魚卵系含む）を生のまま 刺身として食べる事が多く, 加えて過酸化脂質の蓄積 が多い魚介類の干物もよく食卓にあがるため, 日本食 とワインが合わないという印象を持たれているのだと 考えられている ${ }^{8)}$

Novel Method to Reduce Fishy Aftertaste in Wine and Seafood Pairing Using Alcohol-Treated Yeast Cells Toshikazu Tsuji (Central Laboratories for Frontier Technology, Kirin Holdings Company, Limited) 
次に, ワインやその原料であるブドウ果汁から鉄を 低減するにはどうすればよいだろうか。単純に思える が実は大きな 3 つの課題が存在している。1. 安全性, 2. 工業利用可能な簡便性, 3. 鉄のみを除去する特異 性の 3 つである。ワイン中に鉄が $7 \sim 10 \mathrm{mg} / \mathrm{L}$ 程度 存在してしまうと, 混濁の原因になること ${ }^{9)}$ から, ワ イン醉造では古くより，フェロシアン化カリウム（黄 血塩）を添加することで鉄を化学的に沈殿させる除鉄 法が行われてきたが，シアン化物であるということか ら, その安全性や廃棄処理の問題から日本では認可さ

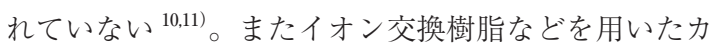

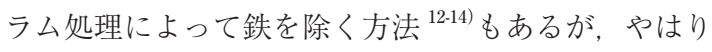
工業利用可能な簡便性にそしい, さらには鉄以外の物 質も吸着してしまい, ワインの風味を損ねてしまうこ

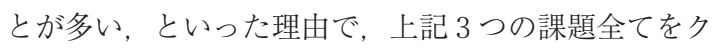
リアできない。そこで, 魚介類との食べ合わせが良い ワインを開発するために, 実用的に利用可能なワイン 中の鉄除去法を目指して, 発酵に用いる酵母を題材に 検討を行った。なお，田村らの報告 ${ }^{4)}$ を見ると，鉄濃 度が $1 \mathrm{mg} / \mathrm{L}$ 以下のワインを選んでくれば,「生臭み」 を発生させやすい素材であるホ夕テの干物と食べ合わ せた場合に, 多くのワインが「弱い生臭み」を感じる， あるいは「ほとんど感じない」程になっている。つま り, 鉄濃度が $1 \mathrm{mg} / \mathrm{L}$ 程度にまで下がったワインがで きれば，魚介料理との食べ合わせ時に，「生臭み」を 感じにくくなる可能性が高い。そこで, 本研究におい ては, ワイン中の鉄濃度 $1 \mathrm{mg} / \mathrm{L}$ を鉄低減の 1 つの目 標として取り扱った。

\section{1 ケ月に及ぶ果汁発酵試験における鉄濃度変 化と酵母の死滅率の関係}

まずは，果汁の発酵中に酵母が鉄をどの程度吸収 · 吸着するのか詳細に調査を行った。予備検討として, いくつかのワイン酵母を用いて果汁発酵試験を実施し たが，ほとんど鉄を吸収・吸着せず，発酵改善での鉄 低減や鉄を多く吸収・吸着するような酵母の育種は難 しいと考えられた。また嫌気条件下では，鉄の取り込 みに関わるトランスポーターの発現が抑制されるとい う報告 ${ }^{15)}$ からも，この結果は正しいと考えられた。 一方, 数多くのワインの種類の中でも経験的に鉄の少 ないものが存在することが知られていた。それが、 シ ユールリーという伝統的な製法で作られたワインであ
る。シュールリーとはフランス語で「オリの上」を意 味する言葉であり, ワインにコク味や旨みなどを付与 するために, 発酵後も酵母などからなるオリをタンク 内に残したまま, 数ヶ月〜 1 年間, ワインとオリを接 触させておく手法である。こうすることで, 酵母の自 己消化が促進され，コク味や旨みの元となる醳母内の アミノ酸やペプチドがワイン中に放出される。この事 実にヒントを得て, 長期間にわたるワイン発酵中の鉄 濃度の変化を詳細に調査することとした。

ワイン酵母 OC-2 を用いて, $20^{\circ} \mathrm{C}$, 静置の条件で, 白ワイン用の果汁で発酵試験を行った。第 1 図に発酵 試験中の鉄濃度の変化と酵母の死滅率, 発酵経過をモ ニターするための Brix を示した。第 1 図 A に示され るように, 発酵開始直後から 10 時間までは, 酵母は 鉄を急速に吸着・吸収しているが，その後徐々に鉄濃 度が上昇する。発酵開始 7 日後にBrix でモニターす る糖分はほほ変化しなくなり (糖切れ), 糖切れ直後 では，発酵開始前とほぼ同じ鉄濃度 $(4.5 \mathrm{mg} / \mathrm{L})$ にな つてしまう。今回の目的の 1 つは, 長時間発酵を続け た場合の鉄濃度の変化を見ることであったため, さら に発酵試験を続けたところ，面白い現象を見つけた。 糖が消費された後 (発酵開始から 100 時間後) に, 死 滅酵母細胞の割合が急激に増加し, それと同時に鉄濃 度が急速に減少し始めた。さらに発酵試験を続けてい くと, 840 時間, 実に発酵開始から 35 日経過すると,

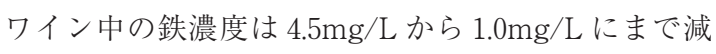
少していた（第 1 図 B)。この結果に基づき,「死滅し た酵母に充分な鉄を吸着する能力がある」という仮説 を立てた。

\section{3. エタノール処理酵母による鉄吸着現象の発見}

上記の仮説を検証するために, 培養したワイン酵母 DV10を一般的な殺菌法である熱処理 $\left(65^{\circ} \mathrm{C}, 1 \mathrm{hr}\right)$ と $70 \%$ エノールの 2 条件で死滅させた。死滅した 酵母を湿潤した状態で白ワイン用の果汁に添加したと ころ, 第 2 図に示すように, エタノール処理した酵母 （ETY : Ethanol-treated Yeast）でのみ顕著な鉄低減 効果が見られた。

熱処理した酵母では, 酵母は 100\%死滅していたが, 鉄を全く吸着していなかった。ETYの鉄低減効果は 菌体添加量を $\mathrm{OD}_{600}=3$ (乾燥菌体重量当りで計算す ると、拈よそ $2.7 \mathrm{~g} / \mathrm{L})$ とすると, 初期鉄濃度 $6.2 \mathrm{mg} /$ 
(A)
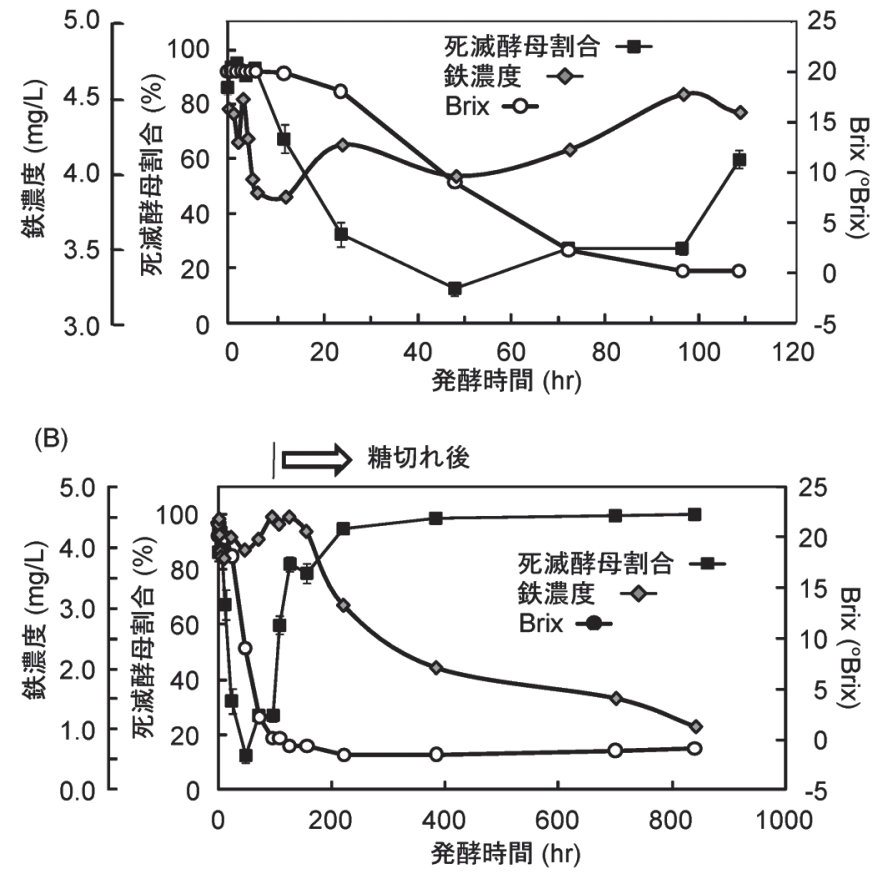

第 1 図 長期間発酵時の白ワイン果汁中の鉄濃度と死滅率の変化: (A) 糖切れ前までの発酵経過, (B) 発酵開始 840 時間までの果汁中の鉄濃度の変化 $\left.{ }^{6}\right)($ 平均值 $\pm \mathrm{SD}, \mathrm{n}=3$ )。死滅率は 蛍光色素 DiBAC4 (3) を用いて, FACS にて蛍光強度の高い細胞をカウントした ${ }^{23)}$

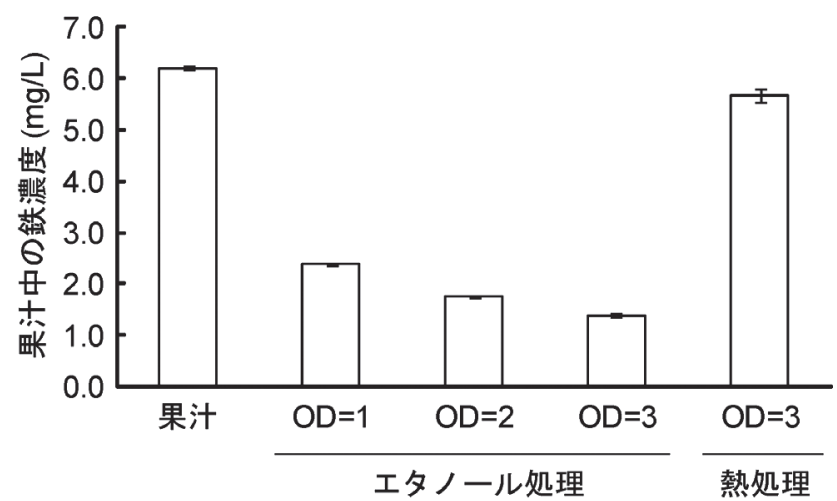

第 2 図 果汁添加時の $\operatorname{ETY}(\mathrm{DV} 10)$ の鉄低減効果 $\left.{ }^{6}\right)$ (平均值 $\pm \mathrm{SD}, \mathrm{n}=3$ ) 添加量は $\mathrm{OD}_{600}$ で示す。

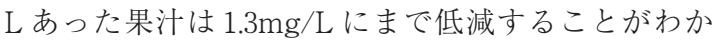

り，非常に効果的な鉄吸着剤であることが示唆された。

また，エタノール処理によって鉄吸着能が付与される のはワイン酵母だけではなく, パン酵母や実験室酵母 として用いられる Saccharomyces cerevisiae やビール 酵母である Saccharomyces pastorianusでも鉄低減効 果が確認できた（第 1 表）。

\section{4. エタノール処理条件の最適化}

次に酵母をエタノール処理する条件を検討した。エ タノール処理濃度が下がることで，より扱いやすい技 術になると考えたからである。ワイン酵母 DV10を用 いて, エタノールの処理時間および濃度と鉄低減効果 の関係を調べた。すると, 第 3 図に示すように, エ夕 
第 1 表 各酵母株を用いた時の果汁の鉄低減効果の比較 ${ }^{6)}$

\begin{tabular}{cccccc}
\hline \multirow{2}{*}{ 菌株名 } & \multirow{2}{*}{ 用途 } & \multicolumn{2}{c}{$1 \mathrm{~g} / \mathrm{L}$ ETY 添加群 } & \multicolumn{2}{c}{$3 \mathrm{~g} / \mathrm{L}$ ETY 添加群 } \\
\cline { 3 - 6 } & & 鉄 $(\mathrm{mg} / \mathrm{L})$ & 鉄除去率 $(\%)$ & 鉄 $(\mathrm{mg} / \mathrm{L})$ & 鉄除去率 $(\%)$ \\
\hline SYT001 $^{22)}$ & 実験室 & 2.5 & 49.1 & 1.5 & 71.2 \\
\hline DV10 & ワイン & 2.7 & 45.6 & 1.4 & 76.9 \\
\hline IFO1127 & ビール & 2.3 & 53.3 & 1.1 & 68.4 \\
\hline IFO1167 & ビール & 2.7 & 45.7 & 1.5 & \\
\hline
\end{tabular}

$70 \%$ エタール処理した酵母（乾燥）を果汁に添加。果汁初期鉄濃度 $4.9 \mathrm{mg} / \mathrm{L}$ 。

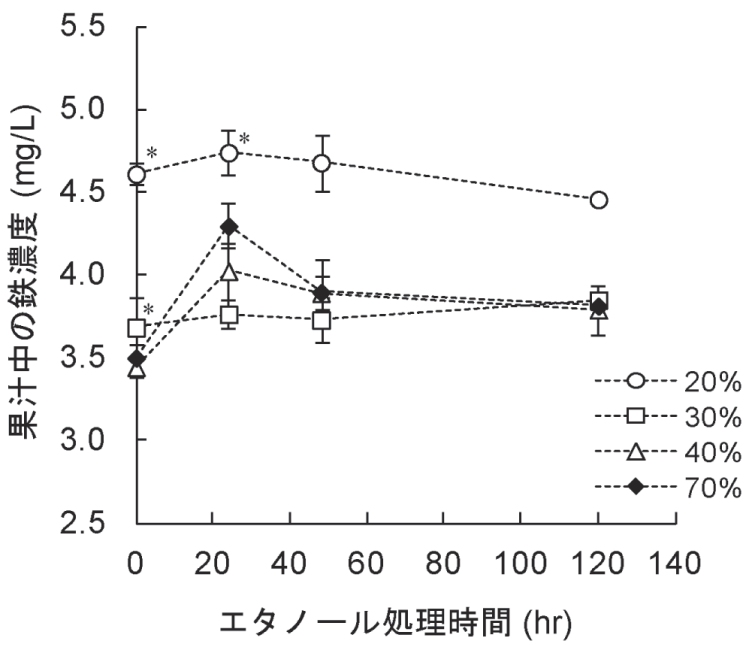

第 3 図 ETY 作製時のエタノール処理濃度と処理時間が 鉄低減効果に及ぼす影響 ${ }^{6)}$ (平均值 $\mathrm{SD}, \mathrm{n}=3$, * エタノール処理で完全に酵母が死滅していないこ とを示す)酵母は DV10を使用し， $\mathrm{OD}_{600}=1$ とな る濃度で添加。果汁初期鉄濃度 $6.2 \mathrm{mg} / \mathrm{L}$ 。

ノール濃度に関わらず，短い時間（30 分以下）でエ タノール処理した場合に, 鉄低減効果が高くなること が明らかとなった。加えて，エタノール処理を長期間 行うことによって, 酵母の重量が減少することもわか った。例えば，70\%（v/v）のエタノールで酵母を処 理した場合，初期重量が乾燥菌体で $95 \mathrm{mg}$ だったもの が, 30 分処理で $95 \mathrm{mg}, 1$ 日処理で $83 \mathrm{mg}, 3$ 日処理 すると $64 \mathrm{mg}$ と初期の 3 分の 1 が失われてしまった。 菌体重量当りの鉄低減量にも変化がなかったため, 処 理時間は 30 分程度と短い方が良いと考えられた。一方， 濃度に関しては，40\%（v/v）以上のエタノールが望ま しいことが明らかとなった。30\%（v/v）以下でも鉄低 減効果はあるが，30\%エタノールで処理した場合には 30 分程度の処理時間だと完全に酵母を死滅させること

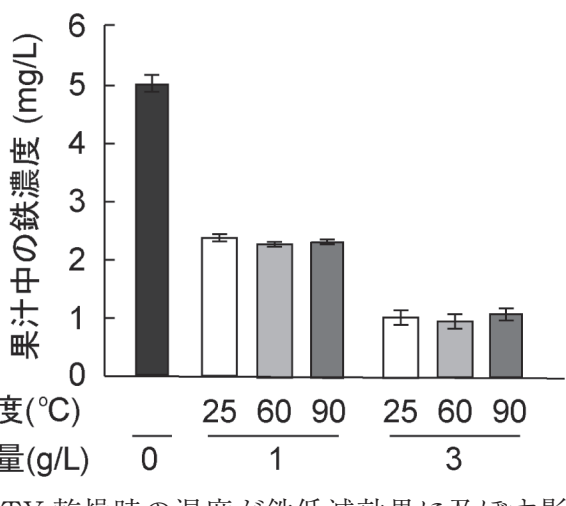

第 4 図 ETY 乾燥時の温度が鉄低減効果に及ぼす影 響 ${ }^{6)}$ (平均值 $\pm \mathrm{SD}, \mathrm{n}=3$ ) 酵母は DV10 を使 用。果汁初期鉄濃度 $5.0 \mathrm{mg} / \mathrm{L}$ 。one-way ANOVA, $P>0.05$ で有意差なし。

はできない（第3 図）ため, 果汁やワインにこの酵母 を添加した際に, 不必要に発酵してしまう, あるいは 香味に影響を与えてしまうことに成りかねない。この 問題に関してはエタノール耐性の低いビール酵母など を選ぶことによって，解決できることがわかった。30\% 程度のエタノールでも酵母を死滅させ，かつ鉄低減効 果を付与できることが明らかとなっている7゙。

第 2 図, 第 3 図の実験では, ETYは湿潤した状態 で果汁に添加されている。しかしながら, 実用的に利 用するには, 一度 ETY を大量に作り, 保管し, 必要 な時に利用するという形が理想である。第 4 図に示さ れるように, ETY 乾燥時の温度が鉄吸着能に与える 影響を検討した結果，一度エタノールで酵母を処理す れば，乾燥温度は鉄吸着能に影響を与えていないこと が示された。

さらに乾燥させたETYを 1 ケ月常温にて保存した 後, 果汁に添加したところ, 保存前後で全く鉄低減効 果は変わらないことも確かめられた (第 5 図)。酵母 


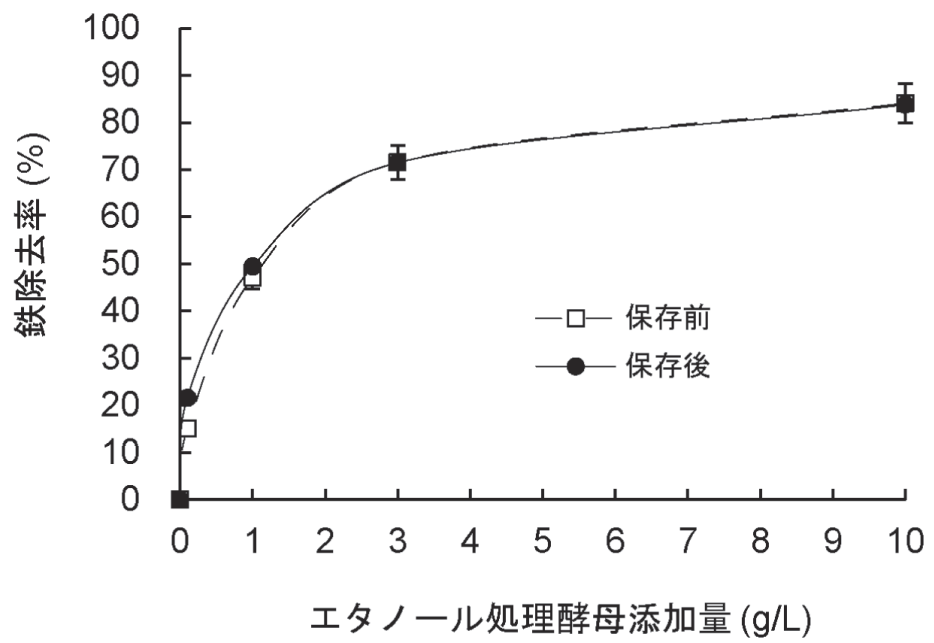

第 5 図 乾燥 ETY の保存時間が鉄低減効果に及ぼす影響 ${ }^{6}$ (平均值 $\pm \mathrm{SD}, \mathrm{n}=3$ ) 酵母は DV10 を使用。果汁 初期鉄濃度 $6.4 \mathrm{mg} / \mathrm{L}$ (保存前), $5.4 \mathrm{mg} / \mathrm{L}$ (保存後)。鉄除去率は初期鉄濃度からの変化率で算出した。

を $1 \mathrm{~g} / \mathrm{L}$ および $3 \mathrm{~g} / \mathrm{L}$ の濃度で果汁に添加すると，果 汁中の鉄は $47 \%$ および $72 \%$ 低減されることが明らか となった（第 5 図）。初期濃度が $1 \sim 10 \mathrm{mg} / \mathrm{L}$ の鉄濃 度の果汁を用いた場合には，ほぼ同じ効率で鉄が低減 されており，初期鉄濃度に依存しない効果も確認でき $た^{7)}$ 。

\section{5. ワイン中の鉄吸着剤としての ETY の利点}

現在日本でワイン製造に用いることができる安全か つ簡便そして香味に影響を与えない鉄吸着剤としてフ イチン酸がある。フィチン酸は穀物や豆類に多く含ま れる物質であり，高いキレート作用を持つ。しかしな がら，高いキレート作用はあるものの，どんな条件で も鉄をキレートできるわけではない ${ }^{11}$ 。Trela らの報 告によれば, フィチン酸と鉄が 1:1 のモル比で含まれ ていて，かつカルシウムとフィチン酸のモル比が 5:1 の場合に $90 \%$ 以上の鉄が低減できることを報告して いる ${ }^{11)}$ 。実際，我々もフィチン酸の鉄低隇効果を調 べてみたが，効果が出る果汁・ワインとほとんど鉄を 低減できない果汁・ワインがあることがわかった。そ こでフィチン酸では鉄を除去できなかったワインを用 いて，ETYが鉄を低減できるかどうかを調査し，第 6 図に示した。

フィチン酸でほとんど鉄が低減できなかったワイン でも，ETYは鉄を低減できることがわかった。興味 深いことに, フィチン酸と ETY $(3 \mathrm{~g} / \mathrm{L})$ を両添加

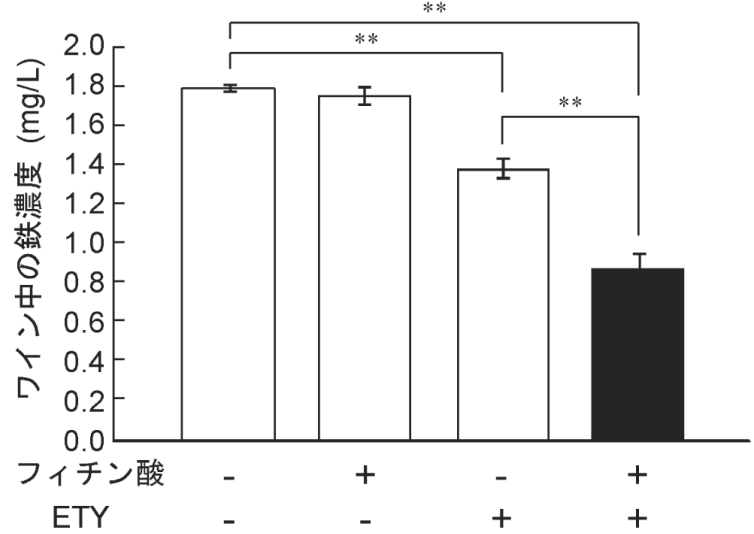

第 6 図 白ワインにおけるETY とフィチン酸の鉄低減 効果の比較と併用による相乗効果 ${ }^{6)}$ (平均值 \pm $\mathrm{SD}, \mathrm{n}=3,{ }^{* *}$; one-way ANOVA, $\left.\mathrm{P}<0.001\right)$ 酵母 はDia yeast(キリン協和フーズ社)を使用。フ イチン酸は $20 \mathrm{mg} / \mathrm{L}, \mathrm{ETY}$ は $3 \mathrm{~g} / \mathrm{L}$ で添加。

(以下, ATY-PA 法と呼ぶ) することで, ワイン中の 鉄を相乗的に低減できることも明らかとなった（第 6 図)。ETYの使用量を $0.5 \mathrm{~g} / \mathrm{L}$ と少なくした場合にも, 同様の相乗効果が確認された。つまり, 鉄低減に必要 な ETYの添加量も減らすことができ, 実用的にも扱 いやすい手法へと洗練することができた。 


\section{6. エタノール以外のアルコールで処理した酵母 の鉄吸着能の評価}

上記で，エタノール処理した酵母に鉄吸着能がある ことを示した。さらに, エタノール以外のアルコール 処理で同様の結果を得ることが出来れば，処理設備の 選択肢の拡大にもつながることから，低級アルコール で処理した酵母の鉄吸着能を評価した。検討の結果, イソプロピルアルコールなどを含んだアルコール処理 酵母（ATY）にも鉄低隇効果があることを示した（第 2 表)。

\section{7. 魚介類と食べ合わせたときの「生臭み」の官 能評価}

アルコール処理した酵母がワイン䁔造に利用できる 鉄吸着剂となるかを判断するために，ATYをワイン に添加した場合に，(1)ワイン本来の香味を変化させて しまうことがないか，(2)「生臭み」が抑えられるのか， を検証することを目的として，官能試験を行った。官 能試験はワインの官能評価経験のある 11 人のパネリ ストに実施してもらった。

まず，(1) ATYがワインに与える影響について調 查を行った。乾燥したETYを $1 ， 2 ， 3 \mathrm{~g} / \mathrm{L}$ の濃度に て，ラボスケール（15L）で果汁から発酵させた白ワ インに添加し, 遠心と濾過助剤にて清澄化して, 官能 評価用のサンプルとした。官能評価には三点識別法を 用いた。ETY 添加ワインと無添加の通常のワインを 3 サンプル中に混ぜ，パネリストに 3 サンプルのうち， どれが他のサンプルと異なるかを指摘してもらった。 計 20 セットの試験をしてもらった結果を第 3 表に示

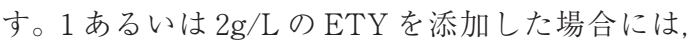

第 2 表 アルコール処理酵母の鉄吸着能の評価 ${ }^{6)}$

\begin{tabular}{cc}
\hline アルコールの種類 & 鉄濃度 $(\mathrm{mg} / \mathrm{L})$ \\
\hline エタノール & $3.36 \pm 0.07$ \\
$\mathrm{n}-$ プロパノール & $4.16 \pm 0.14$ \\
イソプロピルアルコール & $4.06 \pm 0.06$ \\
$\mathrm{n}$ - ブタノール & $3.66 \pm 0.03$ \\
イソアミルアルコール & $3.74 \pm 0.10$ \\
\hline
\end{tabular}

実験室酵母 SYT001 ${ }^{22)}$ をそれぞれ 70\%（v/v）のアルコ ールで処理した後, 乾燥させ, $3 \mathrm{~g} / \mathrm{L}$ の濃度で添加した。 初期鉄濃度は $6.5 \mathrm{mg} / \mathrm{L}$ 。(平均值 $\pm \mathrm{SD}, \mathrm{n}=3$ )
無処理のワインと区別する事はできなかった。一方で, $3 \mathrm{~g} / \mathrm{L}$ の濃度で ETYを添加すると, 無処理のワイン とは区別された。しかしながら，その香味の違いは 「酵母臭の着香」ではなかったことから， $3 \mathrm{~g} / \mathrm{L}$ 以上の ETYの添加は単に香味の変化をもたらす，というこ とが結論付けられた。

次に, (2)の「生臭み」について評価した。イソプロ ピルアルコールで処理した乾燥パン酵母 Dia yeast (キリン協和フーズ社）およびフィチン酸をラボスケ ールで発酵させた白ワインに添加し，上記サンプルと 同様に遠心，濾過助剤にて清澄化した。ワインとの食 ベ合わせ時に「生臭み」を感じやすい魚介類としてホ タテの干物を使用し, ワインはATY 単独, フィチン 酸単独, ATY + フィチン酸求よび無処理の計 4 サン プルを用いた。官能評価の方法はホ夕テの干物を食べ, 続いてワインを飲んだときの「生臭み」の強さを Labeled Magnitude Scale（ほとんど感じない，1.4; 弱い, 6.1 ; 強くも弱くもない, 17.2 ; 強い, 35.4 ; とても強 い, 53.3 ; 想像でき得る限り強い，100） ${ }^{3.20)}$ を用いて 評価した。その結果，ATYを添加したワインはフィ チン酸で処理したワインよりも生臭みを感じにくく, さらにその両方（ATY-PA）で処理したワインは最 も生臭みを感じにくいということが示された(第 7 図)。

無処理ワインで「強いレベルの生臭み」が発生した にも関わらず，ATY-PA で処理したワインでは「弱 いレベルの生臭み」にまで低減できることがわかった。 なお, Two-way ANOVAによって検定を行ったとこ ろ，パネリスト間での有意な差は無く $[F(10,30)=$ $1.97, \mathrm{p}=0.073]$, サンプル間の生臭み強度に有意な 差があることが確認できている $[\mathrm{F}(3,30)=21.1, \mathrm{p}$ $\left.=1.48 \times 10^{-7}\right]$ 。気になるのは生臭み以外に変わった ところが無いか？という点ではあるが，パネリストに 「生臭み」以外で気になることがあれば指摘をする, という条件を伝えて試験を行ったが, 3g/Lの ATY

第 3 表 3 点識別法による ETY 処理ワインと 未処理ワインの香味の比較 ${ }^{6)}$

\begin{tabular}{cccc}
\hline ETY の量 $^{\mathrm{a}}$ & 正答数 & 総試験数 & $P$ \\
\hline $1 \mathrm{~g} / \mathrm{L}$ & 10 & 20 & 0.054 \\
$2 \mathrm{~g} / \mathrm{L}$ & 7 & 20 & 0.182 \\
$3 \mathrm{~g} / \mathrm{L}$ & 11 & 20 & 0.024 \\
\hline $\mathrm{a}$ & エタノール処理した IFO1167 (ビール酵母)
\end{tabular}




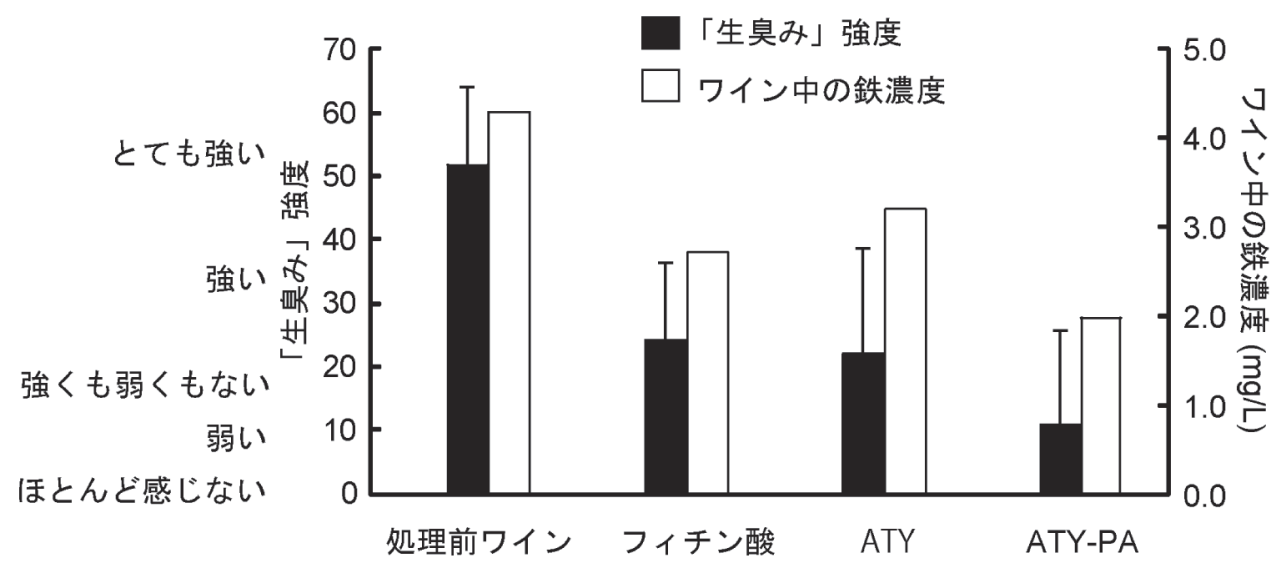

第 7 図 ホ夕テ干物と白ワインとの食べ合わせに扔ける ATY-PA 処理の「生臭み」低減効果 ${ }^{6)}$ (平均值 $\pm \mathrm{SD}, \mathrm{n}=11$ ) 酵母は Dia yeast(キリン協和フーズ社)を使用。フィチン酸は $50 \mathrm{mg} / \mathrm{L}, \quad$ ATY は $3 \mathrm{~g} / \mathrm{L}$ で添加

を添加しているにも関わらず，指摘はなかった。第 3 表で述べたような ETY 添加による香味の変化は, こ の結果からもあまり大きいものではないということが 推測された。

最後にATY 添加によって化学的な分析值に変化が ないかどうかの確認も行った。測定にはGCおよび LC を用いた。有機酸（ギ酸，酢酸，コハク酸、リン ゴ酸, 乳酸, クエン酸, ピルビン酸, リン酸およびピ ログルタミン酸), エステル(酢酸エチル, 酢酸イソ アミル), アルコール（1-プロパノール，2-メチル-1ブタノール，3-メチル-1-ブタノール，イソブタノー ル）抽゙アルデヒド（アセトアルデヒド）の濃度に 顕著な変化はなかった ${ }^{6)}$ 。今回の報告では, 全て白ワ インおよび白ワインの果汁を用いた結果を報告したが, ATY 添加による生臭み低減効果など全ての試験につ いて赤ワインでも同様の効果が確認されている。

\section{8. まとめと今後の展望}

今回, 我々が開発したアルコール処理酵母は, 酵母 という「安全」な素材をワインや果汁に添加し, 遠心 分離などの操作で除くという「簡便な操作」だけで, 「香味を変化させずに」鉄を除くという点でメリット のある鉄吸着剤だと考えられる ${ }^{6)}$ 。ワイン中の鉄は, 土壤や砂埃による果汁への混入, あるいは醸造に使用 する金属性のポンプや配管からの漏れ出しという，実 に多くの要因による ${ }^{19)}$ ため, 混入そのものを防ぐ事
は難しい。また, 発酵時間, 発酵温度や $\mathrm{pH}$ といった その他様々なパラメーターによって, 発酵中の鉄濃度 は増減する ${ }^{9,19,20)}$ ため, 最終的なワインの鉄濃度がど の程度になるかの判断も難しい。今回開発した技術は, ワインと果汁の両方から鉄を低減できるという柔軟性 を持ち合わせ, 醸造設備や原料に応じて, 添加タイミ ングや添加量を変えることができる利点もあると考え ている。

冒頭で述べたように，鉄は沈殿を引き起こす原因に なり，10mg/L 以上になれば，不快な金属味を呈する ${ }^{19)}$ ことも知られている。また, 混濁を引き起こさない比 較的低濃度の場合でも, ワイン中の鉄はフェントン反 応を通じて, フェノール化合物の酸化を触媒し ${ }^{20,21)}$, ポートワインでは硫酸鉄を添加すると酸化が早まると されている ${ }^{9)}$ 。今回, 注目した魚介料理との食べ合わ せ時に発生する「生臭み」も比較的低鉄濃度で起こる 現象であり, ATY-PA 法がこのような課題の解決に も繋がることを期待している。

一方で，この技術にもまだ課題もある。果汁に添加 した場合とワインに添加した場合とで, 鉄吸着量が変 わる（ワインで吸着量が少ない傾向にある）ことや, 鉄が吸着している酵母成分, アルコール処理による酵 母への鉄吸着能付与メカニズムなど, 今後さらなる工 程改善・新素材の探索のために明らかにすべき問題が ある。

本稿で紹介した技術と近い技術は，バイオレメディ 
エーションと呼ばれる環境浄化に関する研究分野でよ く見られる。本稿が醸造分野だけでなく, 他分野の研 究・開発者の参考にもなれば幸いである。

$$
\begin{aligned}
& \text { 〈キリンホールディングス (株) } \\
& \text { フロンティア技術研究所〉 } \\
& \text { 文 献 }
\end{aligned}
$$

\section{文 献}

1) D.Cooper: Wine with food, 87-97, Crescent Books, New York, (1980)

2) J. Simon: Wine with Food, 10-19, Octopus Publishing, London, (1996)

3) A. Fujita, A. Isogai, M. Endo, H. Utsunomiya, S. Nakano, H. Iwata: J. Agric. Food Chem., 58, 4414-4420, (2010)

4) T. Tamura, K. Taniguchi, Y. Suzuki, T. Okubo, R. Takata, T. Konno: J. Agric. Food Chem., 57, 8550-8556, (2009)

5）田村隆幸: 䁔協, 105, 139-147,，(2010)

6) T. Tsuji, K. Kanai, A. Yokoyama, T. Tamura, K. Hanamure, K. Sasaki, R. Takata, S. Yoshida :J. Agric. Food Chem., 24, 6197-6203, (2012)

7) T. Tsuji, S. Yoshida, T. Tamura, K. Sasaki, K. Kanai:WO/2011/148651

8）田村隆幸, 谷口潔, 鈴木由美子, 大久保敏幸, 高田良二, 金野知典：日本味と匂学会誌, 16, 645-648, (2009)

9）財団法人日本䁔造協会編：醸造物の成分，294298, 日本醸造協会, 東京, (1999)

10) J. Pearce: Food Chem. Toxicol., 32, 577-582, (1994)
11) B.C. Trela: Am. J. Enol. Vitic., 61, 253-259, (2010)

12) V. M. Palacios, I. Caro, L. Pérez: Adsorption, 7, 131-138, (2001)

13) G. L. Loubser, D. R. Sanderson, S. Afr. J. Enol. Vitic., 7, 47-51, (1986)

14) M. Feng, J. Mei, S. Hu, S. Janney, J. Carruthers, B. Holbein, A. Huber, D. Kidby: Sep. Purif. Technol., 11, 127-135, (1997)

15) F. R. Hassett, M. A. Romeo, J. D. Kosman: J. Biol. Chem., 273, 7628-7636, (1998)

16) L. Deibner, H. Bouzigues: Ind. Agric. Aliment., 71, 833-837, (1954)

17) P. Vohra, G. A. Gray, F. H. Kratzer: Proc. Soc. Exp. Biol. Med., 120, 447-449, (1965)

18) B. G. Green, P. Dalton, B. Cowart, G. Shaffer, K. Rankin, J. Higgins: Chem. Senses, 21, 323334, (1996)

19) P. Pohl: Trends Anal.Chem., 26, 941-949,(2007)

20) C. S. Ough, M. A. Amerine: Methods for Analysis of Musts and Wines, 2nd ed., 268-288, J. Wiley \& Sons, New York, (1988)

21) A. L. Waterhouse, V. F. Laurie: Am. J. Enol. Vitic., 57, 306-313, (2006)

22) S Yoshida, J. Imoto, T. Minato, R. Oouchi, M. Sugihara, T. Imai, T. Ishiguro, S. Mizutani, M. Tomita, T. Soga, H. Yoshimoto: Appl. Environ. Microbiol., 74, 2787-2796, (2008)

23) R. A. Boyd, S. T. Gunasekera, V. P. Attc eld, K. Simic, F. S. Vincent, A. D. Veal: FEMS Yeast Res., 3, 11-16, (2003) 